\title{
Theft in Case of Need: Reflections on the Ethical-Economic Lexicon of the Middle Ages
}

\author{
Marco Bartoli* \\ LUMSA University, Rome, Italy
}

Received December 27 2017; Accepted January 282018

\begin{abstract}
Is it lawful to steal when you are in a condition of extreme need? Many theologians and canonists between the 12th and 13th centuries wanted to answer this question. It is not just a case of conscience. The problem of theft in case of need is linked to the idea of common possession of the earth's goods and their distribution in case of extreme need. The paper traces the history of one of the most interesting debates in Christian theology, which led to the definition of the ethical-economic lexicon in the Middle Ages.
\end{abstract}

Keywords: Ethics and economics • Middle Ages • Canon law • Scholastic theology • Equitable distribution of goods $\bullet$ Rights of the poor

\section{Introduction}

Is it lawful to steal when you are in a condition of extreme need? For instance, is it lawful to steal to feed your family? This question appeared many times in the theological and juridical texts between the 12th and 15th centuries. As a case in point, Peter of Blois spoke about the case of

a very poor man tortured by hunger and nudity. His wife and his children are dying before his very eyes: unless he steals something, they will certainly die in a short time. He decides to steal something small, choosing to risk his life rather than suffer the unbearable torture of hunger and seeing his family meet with certain death. However, he's caught in the act and, as a result, is condemned to death. The judges did not consider either the misery of the poor man, nor the urgency and necessity that prompted him to steal. Do they believe themselves more righteous than God? The Law of Moses in fact provides for the punishment of the theft with a fine, while civil law itself knows how to distinguish the severity of the different types of theft (Peter of Blois, 1861).

Peter of Blois did not hide his disdain:

Many princes of this land take a lot of care in defending beasts: while people suffer abused as servants, beasts,

1 "Pauperrimus aliquis inhorrescit nuditate et fame, videtque uxorem et familiam suam inedia lethali tabescere; certe eis mors imminet, nisi rapiat aut furetur. Furatur itaque modicum aliquid, dubium vitae discrimen eligens, ut certum periculum mortis et famis angustia importabllis evitetur. Miserabilis homo in furto deprehenditur, et damnatur ad mortem. Judices vero nec miseriam pauperis, nec urgentiam necessitatis, quae ipsum ad furandum compulit, pensant. Nunquld justiores sunt Deo, qui in lege, quam dedit Moysi, pecuniaria mulcta fures puniri decrevit? Nunquid est aequior lex eorum lege imperiali, quam vigilanti studio et exactissima eliberatione sancivit aequitas? Illa equidem inter furem manifestum. et non manifestum circumspecte distinguit, et hunc in duplum, illum vero in quadruplum punit." Peter of Blois, Canon episcopalis id est Tractatus de institutione episcopi (P.L. 207, 1108) (translation of this and other Latin texts are my own). 
like deer, fallow deer, hares enjoy the privilege of great freedom. The beasts can devastate the fields and the gardens of the poor, and no one moves to prevent it. In fact, in our day a sinister law condemns people not just for the capture of animals, but also for the mere suspicion of wanting to capture them. The members that nature has created for the procreation of human beings are cut off, the eyes are extracted, the feet and hands are severed, and the person, who was created in the image and likeness of God, is horribly deformed in contempt of his Creator. ${ }^{2}$

The author, Peter of Blois, was rather an adventurous career clergyman: after studying in Bologna and Paris, in 1166, he moved to Sicily, where he became tutor to King William II. As he was forced to leave the Kingdom of Sicily, he moved to France and then to England, where he was chancellor of the archbishop of Canterbury and eventually secretary of Queen Eleonora, who was widowed by King Henry II. Peter was therefore a prominent public figure, who knew well the ways of the society of his day. Nonetheless, he was first of all a cleric who was especially solicitous for the destiny of ecclesiastics like himself. As Albini (2016) pointed out:

The presence of collective misery appears, in various works [by Pietro di Blois], as a specter, as a danger to be avoided. The fear of a chaotic society emerges, a society in which family ties are lacking and disordered situations are created, that make begging necessary, thus giving rise to the presence of vagabonds, which he describes as deformed, ravenous, semihomuncoli (half-humans). ${ }^{3}$

The story of the man who stole to feed his family in any case touches a problem; this is not only a personal problem but also a general one, because it is an ethicalsocial problem: is it lawful to steal in case of extreme necessity? Pietro di Blois seemed to be inclined toward an affirmative answer, or at least he was scandalized by

2 "Quidam principes terrae de sola immunitate cogitant ferarum, et, hominibus gementibus inter serviles angarias, cervi, capreoli, damae et lepores privilegio summae libertatis exultant. Pauperum segetes et hortos impune depascunt, nec est qui eos arcere praesumat; lex enim funesta homines hodie, non solum de captione ferarum, sed de simplici captionis suspicione condemnat. Succiduntur membra, quae in causam humanae propogationis natura creavit, effodiuntur oculi, pedes etiam manusque truncantur, et homo qui ad imaginem et similitudinem Dei creatus est, in sui Creatoris contumeliam horribiliter deformatur.": Blesensis, Canon episcopalis id est Tractatus de institutione episcopi (P.L. 207, 1110).

3 Albini 2016, p.99, the citation is found in Pietro di Blois, Tractatus Quales sunt (P.L. 207, 1021c). the practice, rather widespread not only in England at that time, of putting to death a thief caught red-handed, without taking into account the state of need that may have led him to steal. According to Peter of Blois, it is absurd that hares and deer of noble families are better protected by the law than the poor suffering from hunger.

The case was studied by Huguccio Pisanus (1961) in a very interesting volume, which was titled as Les pauvres ont-ils des droits? (Tierney 1959). This volume describes, in a comprehensive manner, the debate that took place between the mid-12th century and the middle of the next century about the lawfulness of theft in case of need. The obstacles that, for medieval authors, oppose the lawfulness of such behavior are immediately evident. The first obstacle is given by the biblical text; in Exodus 20:15, it is clearly said that "you will not steal," and the same command is repeated in Deuteronomy 5:19. It is a fundamental text for JudeoChristian tradition: the so-called Decalogue, that is, the 10 commandments that Moses received directly from God on Mount Sinai. The words of Exodus do not mention any kind of exceptions, and since they are words of "divine right," they are an almost insurmountable obstacle to the acceptance of any theft as lawful, albeit in conditions of extreme necessity. An attempt to overcome the problem is to observe that the poor person who resorts to theft to help his family survive does not intend to harm anyone, on the contrary, he only has the intention, in itself positive, to meet the needs of his loved ones. This reasoning is however opposed by a tradition that dates back to Augustine of Hippo, according to which every moral act cannot be evaluated on the basis of intentions, but only on the basis of objectivity. No good end justifies in itself an inherently evil act (Peter Lombard 1971). ${ }^{4}$

The solutions found by the clerics between the 12th and 13th centuries were different, depending on whether they were theologians or canonists. Theologians solved the problem by analyzing the condition of "extreme necessity." The solution was then to say that, in case of extreme necessity (such as during a drought, an earthquake, or other extreme situations), everything becomes common. Therefore, if the poor in case of extreme necessity take the possession of something

4 The reflection on intention is strictly tied to the anti-Abelard polemic, of which Lombard was a protagonist: Cf. Lombardus, Sent., 2,40: "Sed Augustinus evidentissime docet...omnes actus secundum intentionem et causam iudicandos bonos, vel malos, praeter quosdam, qui ita sunt mali ut nunquam possint esse boni, etiam si bonam videantur habere causam..." (Ed. Quaracchi, 1, 558; P.L. 192, 748). Lombard quotes Augustin: Contra Mendacium, 7, 18. (P.L. 40, 528-529) 
that does not belong to them, they do not commit theft because that thing does not really belong to anyone in particular. This is the solution proposed, for example, by Thomas Aquinas (1886-1906):

Is it lawful to steal out of necessity? It would seem not. In fact: 1 . A penance can only be imposed for $\sin$. Now, in the Decretals we read: "Those who forced by hunger or nudity, have stolen food, clothes or animals, (let them) do penance for three weeks." Therefore, it is not lawful to steal out of necessity. 2 . The philosopher writes "there are things that in their very name imply malice," and among them he points out theft. And so, what is evil in itself cannot become good for an honest purpose. Therefore, no one can steal lawfully to meet their own needs. 3 . Humans are bound to love their neighbor as themselves. Now, as Augustine says, it is not lawful to steal in order to give alms to one's neighbor (Augustine of Hippo 2001). So, it is certainly not permissible to steal to provide for one's own needs. On the contrary, in the case of need everything is for common (use). Subsequently, it is not a sin to take another's property, (because) need has made it common property. Answer: The provisions of human law can never derogate from the natural right or the law of God. According to the natural order established by Divine Providence, inferior beings are destined to meet humanity's needs. Therefore the distribution and appropriation of things which comes from human law, do not remove the obligation to provide them for the needs of humankind. Consequently, according to natural law whatever one has in overabundance is meant for the service of the poor. For this reason Ambrose in a text of the Decretals (Dist. xlvii, can. Sicut ii) affirms: "The bread that you set aside belongs to the hungry, the clothes you store belong to the naked, the money that you bury in the earth is the price of the ransom and freedom of the poor person." Since, however, there are many who are in need, and it is impossible to rescue all with the same personal fortune, everyone is entrusted with the stewardship of their own goods in order to use them to help those who are in need. Nevertheless, if the need is so obvious and urgent as to require immediate relief with the things one hasat hand (for example when a person is in some danger that cannot be resolved in any other way), then it is lawful for such persons to satisfy their own need by means by taking either openly or secretly another's property. This naturally is not theft or robbery." 5

5 Aquinas, Summa Theologiae, II,II, 66,7: "Ad septimum sic proceditur. Videtur quod non liceat alicui furari propter necessitatem. Non enim imponitur poenitentia nisi peccanti. Sed extra, de furtis, dicitur, si quis per necessitatem famis aut nuditatis furatus fuerit cibaria, vestem vel pecus, poeniteat hebdomadas tres. Ergo non licet furari propter necessitatem. Praeterea, philosophus dicit, in II Ethic., quod
The solution proposed by the canonists instead started with an analysis of the rights and duties of the rich, that is, of the possessors of goods. Following a tradition that dates back to patristic texts, the property owners own everything they have, but are bound to observe the evangelical precept: Quod superest elemosynam date (with that which is superfluous, gives alms; Luke 11:41) (Paglia 2014). Clerics debate on the concept of superfluous and its variable meaning according to the social status of the person concerned, but all of them share the principle of duty of the wealthy to distribute their surplus goods to the poor (Mollat 1974).

Starting with this shared acquisition, Huguccio of Pisa affirmed that, in case of need and in the absence of the rightful owner, the poor who take what belongs to someone else to feed his family can assume that the legitimate owners were present, they would have gladly agreed to give them what they needed (Muller 1994). In this sense, given that the definition of theft according to Roman law is the removal of a good of others against the will of the owner, one of the requirements that qualify the act as a crime is missing and therefore there is no theft.

The reflection on theft in case of necessity, as is evident, has been at the center of a complex analysis, which concerned the general layout of the societas christiana, i.e. the Christianity, as it was being configured between the 12th and 13th centuries (Capitani 1974). (It was)

quaedam confestim nominata convoluta sunt cum malitia, inter quae ponit furtum. Sed illud quod est secundum se malum non potest propter aliquem bonum finem bonum fieri. Ergo non potest aliquis licite furari ut necessitati suae subveniat.Praeterea, homo debet diligere proximum sicut seipsum. Sed non licet furari ad hoc quod aliquis per eleemosynam proximo subveniat; ut Augustinus dicit, in libro contra mendacium. Ergo etiam non licet furari ad subveniendum propriae necessitati. Sed contra est quod in necessitate sunt omnia communia. Et ita non videtur esse peccatum si aliquis rem alterius accipiat, propter necessitatem sibi factam communem. Respondeo dicendum quod ea quae sunt iuris humani non possunt derogare iuri naturali vel iuri divino. Secundum autem naturalem ordinem ex divina providentia institutum, res inferiores sunt ordinatae ad hoc quod ex his subveniatur hominum necessitati. Et ideo per rerum divisionem et appropriationem, de iure humano procedentem, non impeditur quin hominis necessitati sit subveniendum ex huiusmodi rebus. Et ideo res quas aliqui superabundanter habent, ex naturali iure debentur pauperum sustentationi. Unde Ambrosius dicit, et habetur in decretis, dist. XLVII, esurientium panis est quem tu detines; nudorum indumentum est quod tu recludis; miserorum redemptio et absolutio est pecunia quam tu in terram defodis. Sed quia multi sunt necessitatem patientes, et non potest ex eadem re omnibus subveniri, committitur arbitrio uniuscuiusque dispensatio propriarum rerum, ut ex eis subveniat necessitatem patientibus. Si tamen adeo sit urgens et evidens necessitas ut manifestum sit instanti necessitati de rebus occurrentibus esse subveniendum, puta cum imminet personae periculum et aliter subveniri non potest; tunc licite potest aliquis ex rebus alienis suae necessitati subvenire, sive manifeste sive occulte sublatis. $\mathrm{Nec} \mathrm{hoc}$ proprie habet rationem furti vel rapinae." 
an ethical-economic and ethical-political reflection, which naturally had important social implications. The protagonists of this reflection were clerics, that is, those intellectuals who, especially in Bologna (with the study of law) and in Paris (with theological reflection), were building the overall image of the society in which they lived. This reflection of the clerics was nourished in the texts of the first Christian centuries and in particular of the fourth-century doctrinal elaborations, transmitted in varied ways in the following centuries. For demonstrative reasons, the author would like to present the broad lines of this reflection around two large thematic groups, namely "the duties of the rich (Christophe 1964)," on the one hand, and "the rights of the poor," on the other hand.

\section{Clement of Alexandria}

The history of the relationship between Christianity and the rich is the object of study by historians, exegetes, and theologians. To give an idea of writings of the auctores, i.e. the Church Fathers, quoted by theologians and canonists of the 12th and 13th centuries, it will be enough to cite some points of reference. The first among them is Clement of Alexandria, the Greek author of the second century. His Quis dives salvetur?, i.e. Salvation for the Rich, is perhaps the first text entirely dedicated to a Christian ethical reflection on wealth. Faced with the opinions of those who considered wealth to be completely incompatible with being a Christian, Clement first affirmed that money, on its own, is neither good nor bad, but is an instrument in the hands of people:

An instrument if used skillfully, is skillful; if you are deficient in skill, it is affected by your lack of skill, being itself blameless. Wealth is such an instrument. If one uses it justly it is at the service of justice. If one uses it unjustly it is then at the service of injustice. For its nature is to be subservient, not to rule. We cannot then call to task that which of itself is neither good nor evil. (Of itself) it is not able to be a cause (of anything). Rather call to task that which has the power of using it well or badly. And this thing is the human mind, which possesses both freedom of self-determination and free will in the use of what is assigned to it (Clement of Alexandria 1897).

Based on these considerations, Clement is the first to affirm:

So let no one throw away the riches which benefit also our neighbors. For they are in fact possessions, since they are possessed, and advantageous, inasmuch as they are useful and provided by God for the benefit of humankind; and (riches) are controlled and subjugated to us as material and instruments in order for those who understand it to make good use of it (Clement of Alexandria 1897).

He used here, for perhaps, the first time in history, the expression "the good use of wealth" - an expression that will have a long history in the subsequent writings.

\section{Fourth-century turning point}

A second milestone is represented by what has been described as the turning point of the fourth century. In that century, as everyone knows, by the decision of the emperor Constantine, Christianity first became religio licita, i.e. a lawful religion and then, with Theodosius, the official religion of the Roman Empire. ${ }^{6}$ The turning point was not only religious or political, it was accompanied by a cultural turning point whose greatest representatives were the Cappadocian Fathers, who are well known as the great theologians of Greek patristics (Coulie 1985). At a time when Christianity became the religion of the Emperor and of the whole empire, these bishops were able to exert a decisive influence on the political management of public affairs and on the social structure deriving from it. The fourth-century turning point was described by some eminent scholars as that of the transition from "euergetism," the civic beneficence, to "caritas," the Christian virtue that became a principle of action and social life (Patlagean 1977; Veyne 1976; Brown 2002, pp.6-9).

To expose the differences between the two paradigms of euergetism and charity in simplified terms, we can say that the first difference concerns the recipients of social action: while the euergetism is addressed to all the citizens, regardless of their condition of need, charity is addressed to the poor, be they citizens or foreigners. A second difference concerns the actors of the deed: the euergeti were by definition owners, the privileged, so that they could legitimately expect the plausum, that is, as we can say today, a "reputational benefit." Charity instead has always been required for everyone, i.e., rich and poor, because everyone has the possibility to help in some way those who are worse off than they are, and charity, at least in the Gospel texts, does not provide plausum, but, on the contrary, "when you give alms, do not let your left hand know what your right is doing" (Mt 6:3) (Mara 1980).

6 Codex Theodosianum, 16,1,2: "Cunctos populos, quos clementiae nostrae regit temperamentum, in tali volumus religione versari, quam divinum petrum apostolum tradidisse Romanis religio usque ad nunc ab ipso insinuata declarat quamque pontificem Damasum sequi claret et Petrum Alexandriae episcopum virum apostolicae sanctitatis, hoc est, ut secundum apostolicam disciplinam evangelicamque doctrinam patris et filii et spiritus sancti unam deitatem sub parili maiestate et sub pia trinitate credamus (Codex Theodosianum 1905)." 
Basil of Caesarea is among the important protagonists of this turning point (Pizzolato 2013). After a typical upper classes upbringing, with studies in Athens, Basil chose monastic life and practiced voluntary poverty. As an ordained priest, he demonstrated his new sensitivity to the poor after a recent famine. Brown $(2002,2012)$ described it as follows:

The crisis appears to have been caused by a winter drought such as often afflicts inner Anatolia. No snow or rain fell from an icy, empty sky. The result was not the collapse of the entire ecology of the region. It was, rather, a food shortage, caused by the panic of the rich. Faced with the prospect of a famine of indefinite duration, they were unwilling to make available the grain already stored in their barns.!" Furthermore, Caesarea was unusual in that it lay in the middle of an entirely agrarian region dominated by imperial horse ranches that were crucial for the cavalry of the armies of the eastern frontier. It was not supported by a network of minor towns, which could have served as intermediate points of distribution. Caesarea stood alone. The threat of famine brought the destitute of an entire region to the gates of the city.

Basil did what he could. In a series of sermons, he showed that he had not been educated in Athens to no purpose. He knew how to "move the heart by the incantation of words." The sermons he preached on this occasion were unusually "classical" in style. He challenged the rich to act as euergetai to the poor. He promised them the acclamation of the entire demos of the angels in heaven! Basil's sermons, indeed, were intended to be the swansong of the ancient city. With an indignation rendered heavy with classical resonances, he pointed out to the urban facade of Caesarea. Decaying walls and buildings towered all around, "great cliffs of stone and marble," in which wealth that might have been spent on the poor was frozen in useless stone by the mad drive for "civic" fame!

Eventually, the storehouses were opened. Basil used his own wealth to found a soup kitchen, and could be seen in it, directing his servants as they laid tables for the poor. He even embraced lepers with the kiss of peace! (Brown 2002, pp.39-40).

Basil was among the first to use an "ancient" language, where it was well accepted by the rich of his time, because he reechoed the traditional themes of euereuergetism, i.e. the philanthropy, and plausum, i.e. the approval (even if angelic and not human), to introduce a new type of paradigm, that of caritas (Basil of Caesarea 1857).
These premises were widely developed by the Greek Patriarchs, and particularly by John Chrysostom, whose preaching on the subject of wealth led him to exile and finally to death away from the city of Constantinople, of which he had been the Patriarch (Faus 1991).

\section{Ambrose of Milan}

Ambrose of Milan represents a third milestone in the development of duties of the rich in Christian writings. He has left a legacy of great importance in Western Christianity regarding these issues. The most significant contribution of Ambrose was on the common theme of the origin of goods. This theme has very important biblical roots. An important page of Ambrose's book On Naboth explains it very well:

How far, O rich, do you extend your irrational greed? "Perhaps you alone dwell in the midst of the land?" (Is $5: 8) .^{7}$ Why do you refuse the commonality of nature's goods and claim possession of them only for yourself? The earth was established in communion for all, for the rich and for the poor. Why do you claim for yourself alone the right to land ownership? Nature, which begets everyone poor, doesn't know the wealthy. Nor are we born with clothing or begotten with gold and silver upon ourselves. Naked it brings us into the light (cf. Job 1:21), wanting food, clothing and drink, and naked the earth receives us whom it brought forth, not knowing how to compass our possessions in the tomb. A small plot of land is more than enough for both the poor person and the rich one. The earth, which was not enough for the desires of the rich while they were alive, now contains them completely in little space. Moreover, nature cannot distinguish (rich or poor) when we are born, it does not know how to distinguish when we die. (Nature) creates all equal and welcomes all equally in the womb of the sepulcher. Who can distinguish Nobles among the dead? Remove the dirt and recognize the rich person if you are able. Then clear away another mound and see if you can recognize the poor person. (Nothing shows the difference) except this one fact alone - that more furnishings die with the wealthy (Ambrose of Milan 1997, p.118).

The principle that the earth is common for all people (in latin: commune omnibus... terra fundata est) is expressed very explicitly here. In reality, Ambrose was conscious that he was going beyond the Roman legal

7 All citations of the Sacred Scriptures come from "The New American Bible: Revised Edition" (Oxford University Press, 2011) Online: http://www.usccb.org/bible/books-of-the-bible/index.cfm. 
and philosophical tradition, as evidenced by a famous passage of De Officiis:

They (the philosophers) considered it just that one should treat as communal that which is communal, that is, public property as public, and that which is private (property) as private. But this is not even in accord with nature, for nature has given all things to everyone in common. Indeed, God has commanded that all things to be produced, so that there is nourishment for everyone, and that the earth should be in a certain sense a common possession. Nature, therefore, has produced a common right for all, but greed [usurpation] has made it a private right (Ambrose of Milan 1977, 132). ${ }^{8}$

While Cicero considered consonant with justice the treating of communal things as communal and private things as private, that is the basic principle of nonappropriation for private use of public goods, Ambrose extended the idea of the common goods stating that "nature has poured forth all its gifts indiscriminately for everyone." God commanded that everything was produced so that food was common to all, and the earth was, in a certain sense, the property of all. Nature therefore created the common right, and usurpation (Usurpatio) constituted the private privilege.

This idea has a biblical root, which is strongly expressed in Psalm 24:1 "The earth is the LORD's and all it holds, the world and those who dwell in it." Ambrose conjoined this Judeo-Christian principle with the completely Latin idea of the communion of the goods of the earth in the state of nature. To do so, Ambrose went back to a myth very dear to the Latin tradition: that of the golden age. Brown $(2002,2012)$ explained the procedure as follows:

In canvassing the possibility of a new, more cohesive social order, Ambrose was committed to a view of society that was rooted in a distinctive view of human history. He was the heir of a long tradition of what has been called "ancient primitivism." It was widely believed that there had been a Golden Age somewhere in the past of the human race. It was against the effortless harmony of that

8 Ambrosius, De Officiis, I, XXVIII, 132: "Deinde formam iustitiæ putaverunt, ut quis communis, id est publica pro pubblicis habeat, privata pro suis. Ne hoc quidem secundum naturam, natura enim omnia omnibus in commune profudit. Sic enirn Deus generari iussit omnia ut pastus omnibus communis esset, et terra foret omnium quædam communis possessio. Natura igitur ius commune generavit, usurpatio ius fecit privatum."

9 Ps 23: "Domini est terra, et plenitudo ejus ; orbis terrarum, et universi qui habitant in eo." age that contemporaries measured the present state of society and found it wanting. All that was bad in society came from the slow decline of humanity from a state of social innocence into its present state of social vice. In this, Ambrose looked back not to Cicero but to the more uncompromising Seneca, the Stoic philosopher: "There was once a fortune-favored period when the boundaries of nature lay open to all, for men's indiscriminate use, before avarice and luxury had broken the bonds that held mortals together" [In the words of Vergil's Georgics 1.125-28:] "No ploughman tilled the soil, nor was it right / To portion off the boundaries of property./ Men shared their gain, and earth more freely gave / Her riches to her sons who sought them not." (Brown 2012, p.131).

It is clear, however, that while the myth of the Golden Age was ideally placed in a distant past the JudaicChristian idea of a God as the only effective holder of the possession of all things is a current idea. It is therefore evident that Ambrose made instrumental use of the myth to introduce an idea that, potentially, could be perceived as subversive.

\section{Western monasticism}

The fourth step in the elaboration of Christian writing on the subject of wealth is represented by early medieval monasticism. The contribution of these authors, with their common life in spaces separated from the rest of the society, monasteries, relates to "common use of property." While Ambrose had solemnly affirmed the "common origin of goods," here created the concrete case of a community of men (more rarely of women) who practiced the "common use" of goods. The passage (that becomes the) starting point of this practice is represented by the Acts of the Apostles, which describes the - idealized? way of life of the first Christian community in Jerusalem: "All who believed were together and had all things in common; they would sell their property and possessions and divide them among all according to each one's need" (Acts 2: 44-45). This text was strengthened, in the same Book of Acts, by another passage, in chapter IV:

The community of believers was of one heart and mind, and no one claimed that any of his possessions was his own, but they had everything in common. With great power the apostles bore witness to the resurrection of the Lord Jesus, and great favor was accorded them all. There was no needy person among them, for those who owned property or houses would sell them, bring the proceeds of the sale, and put them at the feet of the apostles, and they were distributed to each according to need. (Acts 4: 32-35) 
The monk, entering the monastery, renounced the personal possession of all his goods, which were distributed to the poor or given to the monastery itself. The Rule of the Master in this regard provided that

When the abbot has at his disposal these goods [those of the new brother], having satisfied the needs of the monastery everything that will seem superfluous, will be sold and the equivalent price will be distributed to the poor on behalf of the soul of the brother himself who gave them, so that what the ignorant brother could not complete, the abbot, as a learned master, could perform in his name (Regula Magistri 1965).

In this way, the goods offered to the monastery became a sacred property. Benedict's rule arrived to invite the monastery's cellarer to "regard all utensils and goods of the monastery as sacred vessels of the altar" (Regula Benedicti 1972). As Todeschini pointed out:

\footnotetext{
A patrimony can be understood as sacred starting with the sacredness of the life of those who run it and the whole managerial dimension concerning this property, the whole tangible reality of this patrimony, up to the trivial practicality of the things useful to table, bed, clothes, daily well-being, can be included in this process of sacralization (Todeschini 2002, p.30).
}

The consequences are illustrated by Todeschini himself:

From the sixth to the tenth centuries, in the Mediterranean West, the place occupied by the church or by the monastery is therefore the place, of a prodigious alchemy: it is here that the materiality of wealth is transformed for the first time from an idol of greed to an organized sacred patrimony, from a private treasure it is changed into a public substance which can have an ordered, mathematic administration (Todeschini 2002, p.35; Weber 1991, p.382).

The word that best expresses this new awareness is caritas, which is understood not only as the sentiment that unites the monks with each other and with God but also as the virtue that presides over the proper use of goods and their administration on behalf of the poor. The opposite of caritas is avaritia, which is understood as a possession that divides, separates, and therefore prevents the collective growth of goods.

This doctrine, elaborated by the clerics, had its first, important, juridical expression in that collection known as the Pseudo-Isidorian Decretals, in which there is a text attributed to Pope Clement I, who said that
The common use of all the things that are in the world must be allowed to everyone, but because of iniquity, someone says something is his own and someone else says something else is of him. Thus, the division between mortals was created [...] But just as neither the air nor the splendor of the sun can be divided, so also the other things, which have been given to all people to be possessed collectively, must not be divided but shared in common. ${ }^{10}$

\section{Eleventh-century reform}

The final step to understand Western Christian writing on theft in case of need is represented by the "Gregorian Reform" of the 11th century. Indeed, it is at this time that the monastic model is imposed on all of Christendom, and the parameters used to sacralize the possessions of the monasteries are used to sacralize the whole world. Continuing to use the words of Todeschini, we recalled that

Between the eleventh and twelfth centuries, was the time in which the Church of Rome is emerging as the institutional center of western Christianity, the unitive caritas, of which the Church Fathers had spoken, becomes the linguistic sign of a social unity, economically visible by ecclesiastical and monastic possessions (Todeschini 2002, p.57).

The so-called 11th-century reform can be represented as the moment when monastic ecclesiology (particularly Cluny's ecclesiology) was applied to the whole of Christianity. The model of the monk, celibate, poor, and unarmed, became more clearly the model of every cleric. We can say that, in the traditional tripartite division of society, in oratores, bellatores, and laboratores, in the 11th century it was the first group, the men of prayer and word, that is, the clerics, who eventually imposed their power over all others, as much on the bellatores, namely on the aristocratic warrior class, as on the laboratores, that is, on all the men and women whose life was marked by labor which is to say by fatigue.

10 "Epistola Sancti Clementis papae de communi vita et reliquis causis suis discipulis scripta hierosolimisque directa", in Migne P.L. 130, 57. Consultabile in http://www.pseudoisidor.mgh.de/pdf/011b.pdf "Communis enim usus omnium, quaem sunt in hoc mundo, omnibus esse hominibus debuit, sed per iniquitatemn alius hoc suum dicito esse, et alius illud, et sic inter mortales facta divisio est. Denique Graecorum quidam sapientissimus haec itar sciens esse ait: Quod inter amicos omnia debent esse communia, communia debere esse amicorum omnia. In omnibus autem sunt sine dubio et coniuges. Et sicut non potest,inquit, dividi aer neque splendor solis, ita nec reliqua, quae communiter in hoc mundo omnibus data sunt ad habendum dividi debere, sed habenda esse communia." 
In addition, clerics applied the monastic economic lexicon, caritas, to all of Christianity. With this procedure, they gave themselves the task of establishing the lawfulness of everyone's earnings and possessions. Beginning with the debate on simony, that is, on the value of spiritual and ecclesiastical goods, they ended up focusing on an elaborate doctrine on usury, which in fact was regarded as any use of money not aimed at the growth of caritas, specifically of the common good of the societas christiana.

\section{Gratian's Concordia}

This brings us to the moment in which, between the 12th and 13th centuries, clerics focused on the problem of theft in case of need, ${ }^{11}$ apparently, a minor issue compared to those of simony and usury, but one that made a great impact in the subsequent debate. The conditions for the clarification of the topic of theft in case of need must be sought in the great foundational work, done by Gratian with his Concordia discordantium canonum of 1140, that marks the beginings of the church law (Tierney 1959). Although Gratian never explicitly addressed the issue of the theft in case of need, there are the auctoritates in the Concordia which will later be used by specialists to determine this concrete case. We can mention some significant passages.

A first important theme developed in the Concordia concerns the issue of the communion possession of goods Gratian quotes Pseudo-Clement's letter contained in the Pseudo-Isidorian Decretals. He's speaking about the common life of the clergy, by which he intended to extend the monastic ideal of the communion of goods. In so doing, Gratian widened the typical monastic ideal of common possession of the monastery's goods to promote the idea of communion possession of all goods of creation. It is important to underline that the auctoritas was attributed by the Pseudo-Isidorian Decretals and therefore also by Gratian to one of the early pontiffs and therefore it enjoyed great authority. It is useful to reread the text, as also reported in Gratian's Concordia:

In fact, the use of all the things that are in the world is a common right and must be allowed to all people. However, because of iniquity, some claim something as their own and someone else says something else is theirs. In this way division among mortals was created.

11 The debate around the issue of theft in the event of extreme necessity has been explained in an egregious way by Couvreur cit. note 2 , which is described in this paper in essential phases.
Eventually a very wise Greek man, knowing that things were this way, affirmed: things held among friends must always be for common use. Even spouses undoubtedly hold everything in common. He adds, "Just as neither the air nor the splendor of the sun can be divided, so too all other things, which have been given to humans to possess them together, must not be divided but shared in common." 12

Second theme is the comparation between the refusal of help and the murder. Starting with the idea of the original common ownership of all things, the Concordia intended to focus on the duties of those who possessed these things. In the first place, Gratian quotes some Church Father equating the refusal to help the hungry to the murder. The first quotation was attributed by Gratian to Ambrose, but in reality, it was a homily of Pope Leo the great: "Feed those who die of hunger. In fact, you kill anyone you could keep alive by feeding, if you do not feed them." ${ }^{13}$ Gratian continued with a text by Caesarius of Arles, which he attributed to Augustine: "those who do not give tithes will be accused of murder before the supreme court of God for all the poor in the their homeland who will die of hunger." (Caesarius of Arles 1953, 146) ${ }^{14}$.

Third theme is the comparation between the refusal of help and the steal. Gratian compared the refusal to help the hunger not only to murder but also to steal. He quoted an important text:

Again Ambrose (Serm. LXXXI) on what we read in the Gospel (Luke 12:16): "There was a rich man whose land produced a bountiful harvest ..." Just as those who are mentally confused due to madness and do not see real things, but rather the fantasies of their passion, so also the mind of misers is sometimes narrowed by the bonds

12 Decretum Gratiani, ca 12, q.1, c.2; Dilectissimis (CIC 676s): "Communis enim usus omnium, que sunt in hoc mundo, omnibus hominibus esse debuit. Sed per iniquitatem alius hoc dixit esse suum, et alius istud et sic inter mortales facta est diuisio. §. 2. Denique Grecorum quidam sapientissimus, hec ita esse sciens, communia debere, ait, esse amicorum omnia. In omnibus autem sunt sine dubio et coniuges. "Et sicut non potest," inquit, "diuidi aer, neque splendor solis, ita nec reliqua, que communiter omnibus data sunt ad habendum, diuidi debere, sed habenda esse communia."

13 "Pasce fame morientem. Quisquis enim pascendo hominem seruare poteris, si non paueris, occidisti.”: D. 86, c. 21. The Concordia attributes this text to St. Ambrose. $\mathrm{H}$. Lio has revealed that we are dealing with a phrase of Leo the Great: Lio 1952, pp.349-366.

14 Sermon 33: “...Et quanti pauperes in locis, ubi ipse habitat, illo decimas non dante fame mortui fuerint, tantorum homicidiorum reus ante tribunal aeterni iudicis apparebit..." (Ed. D. Morin, C.C.S.L., 103, $2^{\circ}$ ed., 146). Cited by Gratian in C. 16 , qu. 1, c. 66. Cfr. Lio 1955, pp.51-58. 
of greed, and they only see gold and silver, only calculate gain, and are more grateful for gold than they are for the sun; their prayer and supplication is always to ask God for money. And a bit further §.1: Sometimes, money arises through the bad art of usury and comes from money itself, but neither satiety nor the end of greed ever arrives. Still further §. 2: But someone says: "There's nothing wrong with it if I do not touch the belongings of others and I keep my own things?" Shameless affirmation! Your own things, did you say? Which ones? From which secret places did you bring them into this world? I wonder with the support of what riches you arrive, when were you born, when you came out from your mother's womb? And a little bit further: §. 3 let no one call their own that which is common, that which they have taken as superfluous or obtained by force. And still: $\S .4$ Is it that God is unfair, that he distributes to us unequally the things necessary for life, so that you are perhaps rich and abundant, while others go lacking and are hungry? And furthermore, why did he want you to make experience of the signs of his generosity and desired to crown another with the virtue of patience? But you take God's gifts and, hidden in your own womb, you don't think you do anything wrong if you keep for yourself what could be beneficial for the life of many? Who, in fact, are so unjust and so avaricious, that they take the nourishment of many not only for their own use, but also as wealth and personal luxury? It is a lesser crime to take away from those who have then it is for those who have in abundance to deny to those who are in need. The bread that you have belongs to the hungry, the garment that you keep (in your closet) belongs to the naked, the money that you bury in the ground is for the rescue and the liberation of the destitute. Know then that you misappropriate the goods of many; many are the people that you can help, if you want. ${ }^{15}$

15 D. 47, c. 8, Sicut hi: Item Ambrosius (Serm. LXXXI) de eo, quod scriptum est in euangelio: "Hominis cuiusdam diuitis fructus uberes agere attulit." Sicut hi, qui per insaniam mente translati sunt, non iam res ipsas, sed passionis suae fantasias uident, ita etiam mens auari semel uinculis cupiditatis astricta semper aurum, semper argentum uidet, semper redditus computat, gratius aurum intuetur quam solem; ipsa eius oratio et supplicatio ad Dominum aurum querit. Et post pauca: §.1. Interdum etiam usurae arte nequissima ex ipso auro aurum nascitur. Sed nec sacietas unquam, nec finis aderit cupiditati. Et infra: §.2. Sed ait: quid iniustum est, si cum aliena non inuadam, propria diligentius seruo? O inpudens dictu! Propria dicis? que? ex quibus reconditis in hunc mundum detulisti? Quando in hanc ingressus es lucem, quando de uentre matris existi, quibus queso facultatibus quibusque subsidiis stipatus ingressus es? Et post pauca: §.3. Proprium nemo dicat, quod est commune plus quam sufficeret sumptum et uiolenter obtentum est. Et infra: §.4. Numquid iniquus est Deus, ut nobis non equaliter distribuat uitae subsidia, ut tu quidem esses affluens et habundans, aliis uero deesset et egerent? an idcirco magis, quia et tibi uoluit benignitatis suae experimenta conferre, et alium per uirtutem patientiae
It is a long quote from a homily that Gratian believed to be Ambrose's. Lio $(1952,1955)$ showed that it is actually taken from a homily by Basil, ${ }^{16}$ which got to Gratian through Rufinus's Latin translation. ${ }^{17}$ This translation was inserted during the early Middle Ages in some ancient collection of Ambrose's homilies and that is why Gratian attributed it to the Bishop of Milan. ${ }^{18}$

The text clearly compares theft by the indigent who in a state of necessity take what belongs to someone else to the theft of those who, possessing goods in abundance, deny them to the indigent who are in need. This reflection led to debates among the Decretists. Some of them wondered if the statement was not simply rhetorical excess. Rufinus for example concluded that the statement must be taken seriously, and therefore the crime of the rich who refuses to help is more serious, but only in the case that the indigent is in serious danger of death. ${ }^{19}$ It is through this reflection that the Decretists elaborate the concept of "extreme necessity," to understand a state of need that is life-threatening (Rufinus 1902, 111).

On the other hand, Gratian also opened the way for reflection concerning the rights of the poor. He quoted, for example, some auctoritas concerning the state of necessity. In the chapter Discipulos of the De consecratione he recalled that Christ had declared innocent the apostles, who, driven by hunger, had eaten some ears of corn. ${ }^{20}$ In the same distinction, there is also an axiom, which Gratian attributed to Pope Felix IV, but which actually goes back to the Pseudo-Isidorian Decretals: necessitas non habet legem (Corpus iuris canonici 1879-1881, 301). ${ }^{21}$

coronare? Tu uero susceptis muneribus Dei, et in sinum tuum redactis, nichil te putas agere iniquum, si tam multorum uitae subsidia solus obtineas? Quis enim tam iniustus tam auarus, quam qui multorum alimenta suum non usum, sed habundantiam et delicias facit? Neque enim minus est criminis habenti tollere, quam, cum possis et habundas, indigentibus denegare. Esurientium panis est, quem tu detines; nudorum indumentum est, quod tu recludis; miserorum redemptio est et absolutio pecunia, quam tu in terra defodis. Tantorum te ergo scias inuadere bona, quantis possis prestare quod uelis.

16 This refers to Basil's homily 6 "in illud dictum Evangelii secundum Lucam : Destruam horrea mea": P.G. 31, 262-278. Cfr. Lio 1952, pp.214-231.

17 Rufino's fairly loose translation of Aquileia in P.G. 31, pp.1744-1753. 18 Cf. P.L. 17, p.594.

19 Rufin, Summa, eod., v. Neque enim minus est criminis: "Hoc intelligitur maxime in eo casu, quando vel ad mortem aut excruciabiliter aliquis a te petens indiget et tu, cum sis habundans, ei non subvenis." (Ed. Singer, 111).

20 De Cons., D. 5, c. 26: "Item ex dictis Apollonii. Discipulos cum per segetes transeundo evellerent spicas et ederent, ipsius Christi vox in nocentes vocat quia coacti fame hoc fecerunt." Gratian attributes the text to a certian Apollonio, but Friedberg claims it belongs to an "unknown author (Corpus iuris canonici 1879-1881)."

21 De Cons., D. 1, 11: "Satius ergo est Missam non cantare aut non audire, quam in his locis ubi fieri non oportet : nisi pro summa necessitate 


\section{Huguccio of Pisa}

Based on the proposed quotations, it is easy to understand how the Concordia has laid the groundwork for the subsequent debate on the specific case of theft in case of need. Gratian, however, as has been said, had not specifically addressed it. The one who truly elaborated the problem of theft in case of need is Huguccio of Pisa, who wrote in his Summa decretorum (concluded after 1188-1190):

Some say that those who compelled by urgent hunger steal are not excused and commit a theft... I on the contrary, I do not believe that the one who is in such a situation sins, that is, someone who uses another's good because of the urgent need of hunger. ${ }^{22}$

Huguccio believed that the indigent who take something of another, in case of need, do not commit theft. He started by putting together the idea of the primordial communion of goods with the need to put them in common in case of necessity. The statement could not be clearer: things are communal by natural law, and the judgment of reason approves this affirmation: all things must be shared with the needy in times of need. In his Summa, Huguccio explained that

(The axiom) "lure naturali omnia sunt communia" does not exclude the "what is one's own", and it doesn't refer to "communal" against "what is one's own," rather the sense of the axiom is as follows: things are communal by natural law and the judgment of reason approves this affirmation: all things must be shared with the impoverished in times of need. According to the natural guide of reason, we believe that we must preserve only what is really necessary for ourselves, and distribute all else to our indigent neighbors. And this interpretation coincides with the words of Jerome [D. 42, § 1, verb. Aliena]: "they are guilty of robbery who want to keep for themselves the things of another in additional to the things that are necessary", I say this, because they are to be shared with others in time of need," and with the

contingat, quoniam necessitas legem non habet." Gratien complète le principe dans un de ses "dicta," Dict. ante C. 1, qu. 1, c. 40: "... necessitas non habet legem, sed ipsa sibi facit legem."

22 Huguccio, Summa, C. 12, qu. 2, c. 11., v. ex inopia: "Sed an excusatur quis propter inopiam urgentem?...Ad hoc dicunt quidam quod non excusatur quin committat furtum et peccet mortaliter; excusatur tamen a graviori peccato et a graviori pena quia minus peccat et minus est puniendus qui necessitate famis, quam qui voluntate committit furtum ... Ego tamen credo quod non peccet quis in tali casu, scilicet cum utitur re alterius propter urgentem necessitatem famis..." (Ms. V, f 186 v, 187 r; Ms. B, f 108 r). Cit. in Huguccio Pisanus 1961, p.56. words of Ambrose [D. 47, Sicut hii]: "let no one call their 'own' what is 'communal,' that is what is granted for his own use, in times of need must be shared with others (Huguccio Pisanus 2006)."23

The problem posed to Huguccio was not the denial of private property, which was the foundation of Roman law, but rather to reconcile it with the Judeo-Christian idea of the communion of goods in natural law. Huguccio's wisdom appeared above all in his comment to D. 47 c.8, which stated:

in this chapter and in many other places it is said that all we have, beyond the necessary things, are the things of others, i.e. they must be shared with others, meaning, with the poor. And since it is affirmed that they belong to them, one asks if the poor, according to this juridical order, can demand these things, if they are denied them. I answer: no, because they do not belong to them, although they are said to belong to them, in the sense that they must be shared with them. They are actually owed to them, but there are many things that are owed, but which cannot be requested according to the legal system, such as dignity, favors and alms, but they can be requested as fitting, that is, with mercy and with a sense of God and piety. [...] - So if some swears to give someone some of their things, if they can they must observe the oath, although, in the aforementioned sense, those things are for the poor. But how to behave in the case of the needy in danger of death, while they have sworn to give to another? I answer: I will (first) rescue the dying, because that is without alternatives, and then if I can, I will absolve what is due to the other. And so, is what is stated in this chapter on the sharing of things a precept? I believe so, according to the word of the Gospel: "Do to others whatever you would have them do to you." (Mt 7:12). ${ }^{24}$

23 Huguccio, Summa, Praefatio Decreti, p.11: "cum dicitur iure naturali omnia sunt communia, non excluditur proprium, nec dicitur commune contrarium proprii, sed is est sensus : iurc naturali, id est iudicio rationis approbante, omnia sunt communia, id est tempore necessitatis indigentibus communicanda. Naturali enim ductu rationis approbamus nobis tantum necessaria retinere, reliqua proximis indigentibus debere distribuere. Que interpretatio colligitur ex verbis leronimi, D. 42 , §1, verb. Aliena, rapere convincitur qui ultra necessaria sibi retinere probatur; aliena dico, id est aliis tempore necessitatis communicanda. - et ex verbis Ambrosii, D. 47 , Sicus hii, ut nemo dicat proprium quod est commune, id est tantum propriis usibus concessum quod tempore necessitatis est aliis communicandum."

24 Huguccio, Summa, $4^{\circ}$ Ad D. 47, c. 8. "Sed cum in hoc capitulo et in multis aliis locis dicatur quod omnia nostra preter necessaria sint aliena, id est aliis scilicet pauperibus, communicanda, et sepe dicatur quod sint eorum, queritur an pauperes ordine iudicario possint illa petere si negentur. Resp. Non, quia non sunt eorum, licet dicantur esse 
Huguccio retained the fundamental principle of private property, whose respect is essential to the legal system, according to the tradition of Roman jurists, but he combined it with the principle of the necessary sharing of goods, limiting it to the case of extreme necessity. His final statement that the sharing of goods in time of need falls under the Gospel precept has important consequences. In the grouping of Christian people into clerics and laities, which became current in the 12th century thanks to Gratian's Concordia, clerics were also required to observe the evangelical counsels, while the laities were only required to observe the precepts. To affirm that the sharing of goods is a precept means to say that not only the clerics but also all the laities are held to observe it.

It was still necessary to justify the fact that the poor man, taking possession of something of another person, although in a situation of extreme necessity, went explicitly against the biblical precept: "you will not steal."

eorum, quia sunt eis communicanda. Revera eis debentur, sed multa debentur que tamen peti non possunt ordine iudiciario, ut dignitates et dispensationes et elemosyne, sed possunt peti sicut debentur, scilicet misericorditer et intuitu Dei et pietatis. - Unde si quis iurat dare talia sua, si potest debet servare iuramentum, licet predicto modo sint pauperum. Quid si quis indiget ad mortem et iuravi alii dare? Resp. Subveniam morienti, quia adhuc illud inevitabile est, et postea persolvam aliud si potero. - Sed numquid est preceptum quod dicitur in hoc capitulo de communicatione rerum? Credo quod sic secundum illum evangelicum: "Omnia quecumque vultis ut faciant vobis homines, et vos eadem facite illis." cit. in Huguccio Pisanus 1961, APP. 2, pp.295-96.
Huguccio's solution was, in many respects, brilliant: he used the definition of theft elaborated by Roman jurists. In the Corpus Iuris Civilis, Huguccio could read Gaius's definition according to which theft is in general the crime of someone who takes the possession of something of another, without the consent of the owner (invito domino) (Corpus luris Civilis, ed. Krueger 1892-1895, 147). ${ }^{25}$ The very clause invite domino, allowed for rereading the case of theft in case of extreme necessity. Huguccio put the case of a poor person in dire need who takes someone else's possession, while the owner is absent. Given the precept of the sharing of goods in case of need, the poor could legitimately think that the owner, if present, would have gladly donated the thing needed; therefore, Huguccio concluded that

Those who in case of necessity [appropriate something of another person] they do not commit theft, because they believe or could believe that the owner would have allowed it. ${ }^{26}$

25 "Furtum autem fit non solum cum quis intercipiendi causa rem alienam amovet, sed generaliter cum quis rem alienam invito domino contrectat": Gaius, Institutes, 3,195 [edizione P. Krueger, p. 147] la definizione venne poi inserita nel Corpus luris Civilis, Inst. 4, 1, 6.

26 Huguccio, Summa, ad C. 12, qu. 2, c. 11, v. ex inopia: "Ego tamen credo quod non peccet quis in tali casu, scilicet cum utitur re alterius propter urgentem necessitatem famis. Et in premisso capitulo $\mathrm{B}$ (urchardi) Si quis per necessitatem nec committit furtum, quia aut cre dit, aut debet credere dominum esse permissurum.

\section{References}

\section{Sources}

Ambrose of Milan, De Officiis, Opera Omnia di Sant'Ambrogio, 13, Città Nuova, Roma, 1977.

Ambrose of Milan, De Nabuthe Jezraelita, Opera Omnia di Sant'Ambrogio, 6, Città Nuova, Roma, 1986. English translation: Ramsey B., Ambrose, London, New York, 1997.

Augustine of Hippo, Contra Mendacium, Opera Omnia di Sant'Agostino, VII/2, Città Nuova, Roma, 2001.

Basil of Caesarea, Opera, ed. Migne, Patrologia Graeca, XXXI, Paris, 1857.

Caesarius of Arles, Sermones, ed. S., Germain Morin, CCSL, 2, Turnhout, Brepols, 1953.

Clement I pope, Epistola sancti Clementis papae de communi vita et reliquis causis suis discipulis scripta hierosolimisque directa, ed. Migne Patrologia Latina, 130, col. 57. Available at: http://www. pseudoisidor.mgh.de/pdf/011b.pdf

Clement of Alexandria, Quis dives salvetur?, ed. Barnard P.M., Cambridge, 1897.
Codex Theodosianum, In: Theodosiani libri XVI cum Constivtionibus Sirmondianis et Leges novellae ad Theodosianum pertinentes, ed. Mommsen T., Meyer P.M., Berlin, 1905.

Corpus iuris canonici, ed. Friedberg E., Leipzig, 1879-1881.

Corpus iuris civilis, ed. Krueger P. (et al.), Berlin, 1892-1895.

Huguccio Pisanus, Summa decretorum, 1, I-XX, ed. Prerovsky O., Monumenta iuris canonici, Biblioteca Apostolica Vaticana, Città del Vaticano, 2006.

Huguccio Pisanus, Summa decretorum, Dist. 47, c. 8 , 293-296, ed. Couvreur 1961.

Peter Lombard, HYPERLINK "https://en.wikipedia.org/ wiki/Sentences" Four Books of Sentences, Ed. Quaracchi, 1,520, P.L. 192, 748.

Peter of Blois, Canon episcopalis id est Tractatus de institutione episcopi, in Petri Blesensis Bathoniensis Archidiaconi Opera Omnia Petrus Blesensis, 
ed. Gilles J.A., Oxford 1861; other edition: Migne Patrologia Latina, 207, LXI-LXXXXII.

Peter of Blois, Tractatus Quales sunt ed. Migne Patrologia Latina, 207, 1021, Paris, 1855.

Regula Benedicti, ed. Vogüé A.D., Le Cerf, Paris, 1972.

Regula Magistri, ed. Vogüé A.D., Le Cerf, Paris, 1965.

Rufinus (Decretist), Die Summa Decretorum des Magister Rufinus, Singer H. (Ed.), Paderborn, 1902.

Rufinus of Aquileia, Migne, Patrologia Greca 31, 1744-1753.

Thomas Aquinas, Summa theologiae cum Supplemento et commentariis Caietani, edition Leonina, t. IV-XI, Rome, 1886-1906.

\section{Studies}

Albini G., Poveri e povertà nel Medioevo, Roma, 2016.

Brown P., Poverty and leadership in the later Roman Empire, Hanover, London, 2002.

Brown P., Through the eye of a needle. Wealth, the fall of Rome, and the making of Christianity in the West 350-550 AD, Princeton. Translated: Per la cruna di un ago. La ricchezza, la caduta di Roma e lo sviluppo del cristianesimo, 350-550 d.C. (2014), Einaudi, Torino, 2012.

Capitani O. (Ed.), La concezione della povertà nel Medioevo, Bologna, 1974.

Christophe P., Les devoirs moraux des riches. L'usage chrétien du droit de propriété dans l'Ecriture et dans la tradition patristique, Paris, 1964.

Couvreur G., Les pauvres ont-ils des droits? Recherches sur le vol en cas d'extrême nécessité depuis la Concordia de Gratien (1140) jusqu'à Guillaume d'Auxerre (+1231), Libreria Editrice Univ. Gregoriana, Roma, 1961.

Coulie B., Les richesses dans l'œuvre de Grégoire de Nazianze. Étude littéraire et historique (coll. Publications de I'Institut orientaliste de Lou- vain, 32), Louvain-la-Neuve, 1985.
Faus J.I.G., de Cristo V., Los pobres en la teología y la espiritualidad cristianas, Antologia comentada, Madrid, 1991.

Lio $\mathrm{H}$., Pasce fame morientem..., Antonianum, 27, 349-366, 1952.

Lio H., Osservazioni critico-letterarie e dottrinali sul famoso testo: Proprium nemo dicat... e testi connessi, Franciscan Stud, 12, 214-231, 1952.

Lio $\mathrm{H}$., Le obbligazioni verso i poveri in un testo di $\mathrm{S}$. Cesario riportato da Graziano... con falsa attribuzione a S. Agostino, Studia Gratiana, 3, 51-58, 1955.

Mara M.G. (Ed.), Ricchezza e povertà nel cristianesimo primitivo, Roma, 1980.

Mollat M., Etudes sur l'histoire de la pauvreté. Moyen Age-XVle siècle, 2, Paris, 1974.

Muller W.P., Huguccio. The life, works, and thought of a Twelfh-Cetury jurist, Washington DC, 1994.

Paglia V., Storia della povertà. La rivoluzione della carità dalle radici del cristianesimo alla chiesa di papa Francesco, Rizzoli, Milano, 2014.

Patlagean E., Pauvreté économique et paauvreté sociale à Byzance, 4e-7e siècle, Ecole des Hautes Etudes en Sciences Sociales, La Haye. Translated: Povertà ed emarginazione a Bisanzio, Laterza Roma-Bari, 1985, 1977.

Pizzolato L.F., Povertà e ricchezza in Basilio, In: Basilio di Cesarea, La cura del povero e l'onore della ricchezza. Testi dalle Regole e dalle omelie, Milano, 7-151, 2013.

Tierney B., Medieval poor 1aw. A sketch of canonical theory and its application in England, Berkeley, Los Angeles, 1959.

Todeschini G., I mercanti e il tempio. La società cristiana e il circolo virtuoso della ricchezza fra Medioevo ed Età Moderna, II Mulino, Bologna, 2002.

Veyne P., Le pain et le cirque. Sociologie historique d'un pluralisme politique, Paris, 1976.

Weber M., Histoire économique. Esquisse d'une histoire universelle de l'économie et de la société, Paris, 1991. 